\title{
Development of chili pepper ganache filled chocolate in artisan chocolate production, determination of sensory and physicochemical characteristics
}

\author{
Berkay SEÇUK ${ }^{1 \star}$ (D), Yılmaz SEÇİM ${ }^{2}$
}

\begin{abstract}
Chocolate can be produced in plain, flavored and filled chocolate shapes. This study aimed to develop the filling material (ganache), which is one of the main ingredients of filled chocolate production, in chili taste. Firstly, for this purpose the production processes to be used were determined and different chili filled ganache were developed with, these fillings became the final product of control group (CG) ganache, powdered chili pepper (PCP) ganache and chili pepper seed oil (CPS) ganache filled chocolate. The consumable status of the produced chili ganache filled chocolate samples was determined by the sensory analysis and physicochemical analysis methods. All samples were stored for 30 days and analyzed at 0,15 and 30 days. As a result of sensory analysis, it was found that CPS ganache filled chocolate samples were more preferable than PCP ganache filled chocolate samples in terms of color and brightness $(\mathrm{p}<0.05)$. When the samples were evaluated from the physicochemical point of view, it was determined that they have gained more hardness as of the $30^{\text {th }}$ day, $\mathrm{L}^{*}$ values (brightness) have decreased and $\mathrm{b}^{\star}$ values increased conversely. Viscosity measurement showed, CPS ganache has less viscosity compared to control group and PCP samples.
\end{abstract}

Keywords: artisan chocolate; chili pepper ganache; chocolate production; sensory characteristics; physicochemical characteristics.

Practical Application: Determination of chili ganache chocolate physicochemical properties and sensory level.

\section{Introduction}

Chocolate is produced with the cocoa mass obtained from the bitter seeds of the cocoa tree, which is believed to originated from the Amazon and Orinoco valleys, which are unique to South America (Afoakwa, 2010: 1; Yilmaz, 2018: 27). With the different products added to this mass, chocolate has become a food with high nutritional value, energy-giving and enjoyed by all people (Kaya \& Şekeroğlu, 2012: 23). Chocolate, a complex emulsion, is a food that activates the pleasure-related centers of the human brain during consumption (Afoakwa et al., 2007: 290).

Chocolate is almost unique due to the fact it is solid at normal room temperatures and melts easily in the mouth. This is because the main fat, called cocoa butter, keeps all the solid sugar and cocoa particles together at temperatures below $25^{\circ} \mathrm{C}$. However, it is liquid in the mouth at body temperature, therefore chocolate becomes a smooth liquid when heated in the mouth. With its different texture and taste, chocolate has an attractive perception for most people (Beckett, 2008: 1). Chocolate is a dense solid particle suspension in which the average solids concentration is approximately between 60 and $70 \%$, with sugar and milk components dispersed in a continuous fat phase consisting mostly of cocoa mass and butter (Afoakwa, 2010: 94). There are various substances in the production of chocolate and other cocoa-based products. Basically, raw materials such as cocoa mass, cocoa powder, cocoa butter, vegetable oils, sugar, dairy products, emulsifiers and aroma are used in the production of these products (Özat, 2018: 46). There are three main types of chocolate. These are bitter chocolate, milk chocolate and white chocolate, and the composition of each one is different (Üzümcü, 2017: 8). Ruby, which is the fourth type of chocolate and started to be used as of 2017, was added to these three types of chocolate today (Günel, 2018). Chocolate can also be grouped in three different ways. These are known as plain, flavored and filled chocolate (Palacioğlu, 2003: 3). Chocolate is basically made by mixing cocoa mass and sugar. Later, milk powder was added to chocolate upon its production and this product was named milk chocolate (Kaya \& Şekeroğlu, 2012: 23). White chocolate, on the other hand, was produced after these two varieties and took place in the market as a chocolate without cocoa mass content (Beckett, 2008: 8).

This study aims to develop the filling material (ganache), which is one of the main ingredients of filled chocolate production, in chili taste. In the light of these purposes, the production processes were determined to initiate the process and chili ganache fillings with different sources of chili were developed. The sub-objectives of the study will be to transform these developed ganache fillings into chocolate samples with chili ganache filling, which is the final product, to determine the consumable status by sensory analysis method and to determine the texture and structure properties of the fillings by physicochemical analysis. All samples were stored for 30 days and analyzed at $0^{\text {th }}, 15^{\text {th }}$ and $30^{\text {th }}$ days.

${ }^{1}$ Program of Cookery, Department of Hotel, Restaurant and Catering Services, Yalvaç Vocational School, Isparta University of Applied Sciences, Kılıçarslan Campus, Yalvaç, Isparta, Turkey

${ }^{2}$ Department of Gastronomy and Culinary Arts, Necmettin Erbakan University, Köyceğiz Campus, Meram, Konya, Turkey

*Corresponding author: berkaysecuk@isparta.edu.tr 
The obtained findings were evaluated by comparison with the studies in the literature in relation to chocolate samples prepared with different additives.

\section{Materials and methods}

\subsection{Materials}

In the study, the production was carried out using raw materials obtained from various companies and chain stores as material. In the production of chili ganache filling, white chocolate produced as drops with minimum cocoa solids substance ratio: $28 \%$, minimum cocoa butter ratio: $29.5 \%$, minimum milk fat ratio: $6.3 \%$, minimum skim milk ratio: $16.7 \%$ white chocolate (Barry Callebaut AG, Switzerland), unsalted butter with minimum $82 \%$ milk fat ratio (Bahçıvan Gıda San. Tic. A.Ş., Turkey), whipping cream with minimum 35\% milk fat ratio (Danone Tikveșli Gıda ve İçecek San. Tic. A.Ş., Turkey), red hot chili pepper (Bağdat Baharatları Gıda San. Tic. Ltd. Şti., Turkey), 100\% pure chili pepper seed oil (Casel İlaç San. Tic. Ltd. Şti., Turkey) were used.

In the transformation of the produced chili pepper ganache into the final product, the chili pepper ganache bitter chocolate, bitter chocolate produced as drops with minimum cocoa solids substance ratio: $54.5 \%$, minimum fat ratio: $36.6 \%$, minimum milk ratio: 0\% (Barry Callebaut AG, Switzerland) was used.

\subsection{Methods}

In the research, two different methods were determined for the production of chili ganache filling. In one of these, the source of chili pepper was powdered chili pepper while the other sample was chili pepper seed oil. Before the determination of these two methods, three different chocolate masters were interviewed and a sample control group (CG) ganache was developed for the study by comparing the CG ganache recipes received after these interviews (Table 1).

Sample ganaches were obtained as a consequence of the additions made on the developed CG ganache. Preliminary trials were carried out during the production of chili ganache, and it was found that chili pepper seed oil was bitterer than powdered chili pepper during the additions. The preliminary findings show that $50 \%$ more chili sources were used in the powdered chili pepper ganache while developing chili ganache. All ganache and chocolate samples produced during the study process were produced by subjecting to three repeats. Thus, three samples were taken for each product and evaluated in the analysis phase, and the standardization level was tried to be raised by taking the averages of the data obtained at the end of the process.

Table 1. Standard production recipe of CG ganache.

\begin{tabular}{lcc}
\hline \multicolumn{3}{c}{ Control Group Ganache } \\
\hline Products & Weight (gr) & Percent (\%) \\
\hline Cream & 270 & $31.60 \%$ \\
White chocolate & 510 & $59.60 \%$ \\
Butter & 75 & $8.80 \%$ \\
Total: & 855 & $100 \%$ \\
\hline
\end{tabular}

Production of ganache starts with cold cream, afterwards the cream is brought to boiling point, butter is added and melted, and then chocolate is added to this mixture taken from the heat source, melted, and the mixture is brought to $27-29^{\circ} \mathrm{C}$. The production stage that differs from the CG ganache is the chili sources added to the mixture after the ganache is brought to $27-29^{\circ} \mathrm{C}$. Therefore, these additions proved that two different ganache products have been produced (Table 2).

In the final stage, bitter chocolate was used as a ready-to-use raw material in the production of chili ganache filled chocolate, and the drop-shaped chocolate was first melted and then shaped by means of molds (Figure 1). The production technique used in the melting and molding process is melting on water at boiling point (bain-marie) and the traditional hand tempering method. Hand tempering, which is one of the most preferred methods in the use of ready-made raw materials, is a method chosen in artisan, boutique chocolate production by small businesses. For standardization, same chocolate molds used were used for both samples during production.

\subsection{Storage of samples}

The samples produced for the study were stored in a refrigerator which is only used for chocolate storage and consists of wooden shelves to prevent moisture formation at $16-18^{\circ} \mathrm{C}$ for 30 days. The samples produced before storage were prepared for the storage with the product number and repetition code and placed in individual protective capsules (Figure 2). In addition, the chocolates were packaged separately for the analysis to be carried out on day 0,15 and 30 , with the aim to prevent confusion.

\subsection{Sensory analysis}

In order to apply the sensory analysis method in the study, 10 expert panelists who have previously tasting experience in the field of study, were determined as emphasized by Lawless \& Heymann (1998). It was aimed to ensure consistency in the analysis by tasting with the same panelists on all measurement days $\left(0^{\text {th }}\right.$, $15^{\text {th }}$ and $\left.30^{\text {th }}\right)$. The samples were compared in terms of qualities such as color, brightness, hardness (Silva et al., 2018: 8841), chili taste and smell in the sensory analysis evaluation form. It was aimed to determine the acceptability levels by scoring such as 1: very bad, 2: bad, 3: acceptable, 4: good, 5: quite good based on these qualities.

\subsection{Physicochemical analysis}

\section{Texture analysis}

While analyzing the texture in the study, hardness levels of the samples were determined by the penetration technique. Texture Analyzer Model TA.XT-plus (UK) device was used for the measurements to be performed on samples. A crawler probe was used in the measurement and the probe was contacted with the ganache inside by penetrating the shell surface of chocolates. Thus, it is aimed to get accurate results in the measurements to be made. During the measurements, three measurements were 
Table 2. Standard production recipe of chili ganache filling.

\begin{tabular}{|c|c|c|c|c|c|}
\hline \multicolumn{3}{|c|}{ Powdered chili pepper ganache } & \multicolumn{3}{|c|}{ Chili pepper seed oil ganache } \\
\hline Products & Weight (g) & Percent $(\%)$ & Products & Weight (g) & Percent (\%) \\
\hline Cream & 270 & $30.50 \%$ & Cream & 270 & $31.00 \%$ \\
\hline White chocolate & 510 & $57.60 \%$ & White chocolate & 510 & $58.60 \%$ \\
\hline Butter & 75 & $8.50 \%$ & Butter & 75 & $8.60 \%$ \\
\hline Powder chili pepper & 30 & $3.40 \%$ & Chili pepper seed oil & 15 & $1.70 \%$ \\
\hline Total: & 885 & $100 \%$ & Total: & 870 & $100 \%$ \\
\hline
\end{tabular}

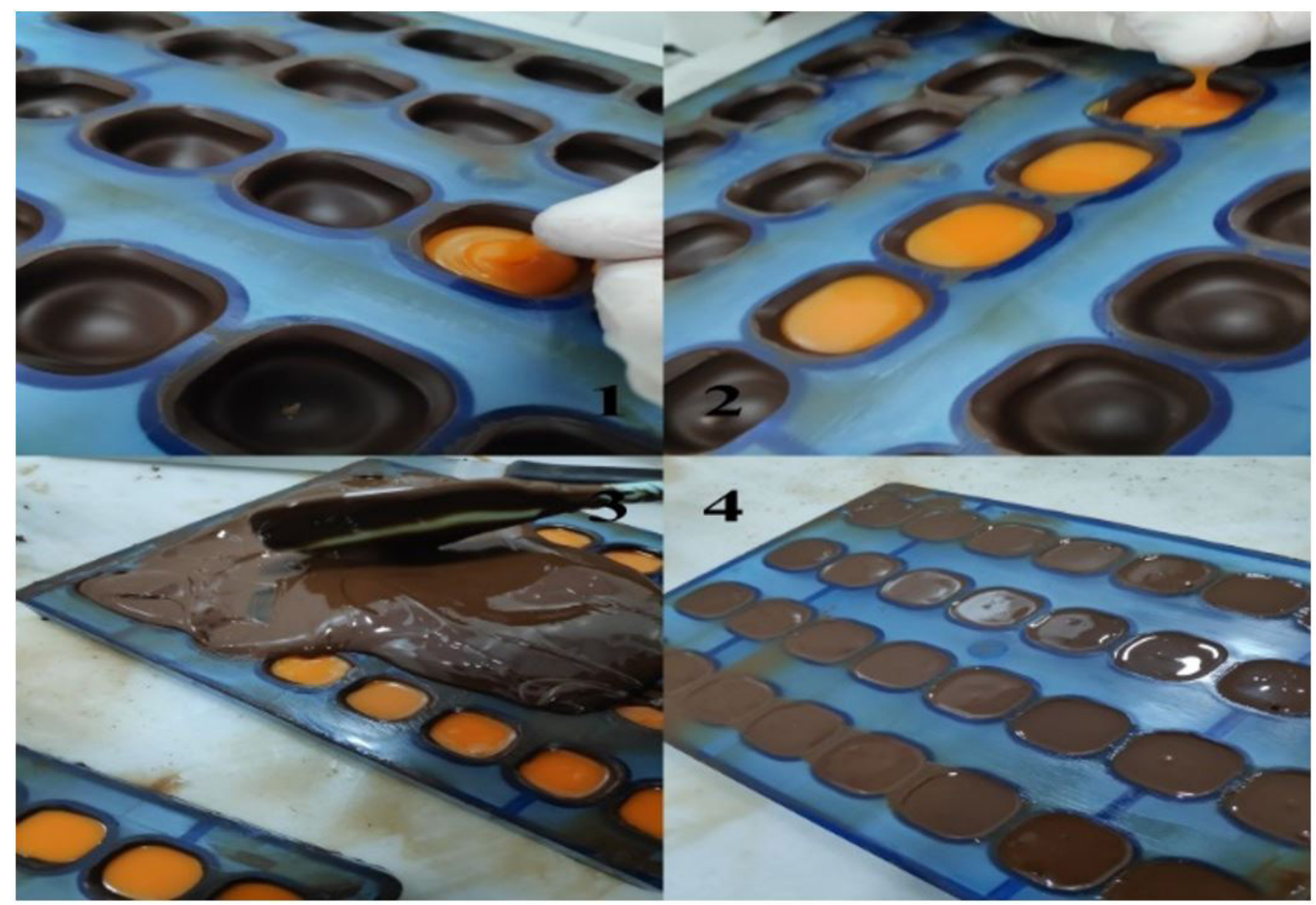

Figure 1. Making process of chili ganache filled chocolate 1-2; adding ganache to chocolate shells, 3; adding chocolate to cover ganache fillings, 4; removing excess chocolate from the mold and scraping the chocolate mold.

made for each repetition and the hardness (n) was calculated by taking the averages.

\section{Color analysis}

In the study, an automatic color determination device (Minolta Color Reader CR-400) was used to determine the color properties of the control group and chili ganache samples filled chocolate, also all measurements were made with three repetitions. During the measurement, the CIE L $\mathrm{L}^{\star}, \mathrm{a}^{*}, \mathrm{~b}^{*}$ (Commission Internationale'de L'Eclarirage) color range measurement system recommended by the International Commission on Illumination (Color) in 1976 was taken as reference.

\section{Viscosity analysis}

Brookfield viscometer was used for viscosity measurements (Brook Field DV II Viscometers 1998). Before the measurements, the ganache in the beaker was brought to $30^{\circ} \mathrm{C} .500 \mathrm{~mL}$ ganache was placed in the beaker for measurements. The device was brought to a speed of $10 \mathrm{rpm}$. The device was operated by dipping the spindle into the ganache inside the beaker. It was waited until a fixed value was read on the indicator; the results were read in "cP" on the display.

\subsection{Statistical analysis}

The data collected as a result of the analysis were assessed with the ANOVA Friedman test using IBM SPSS Statistics 22 


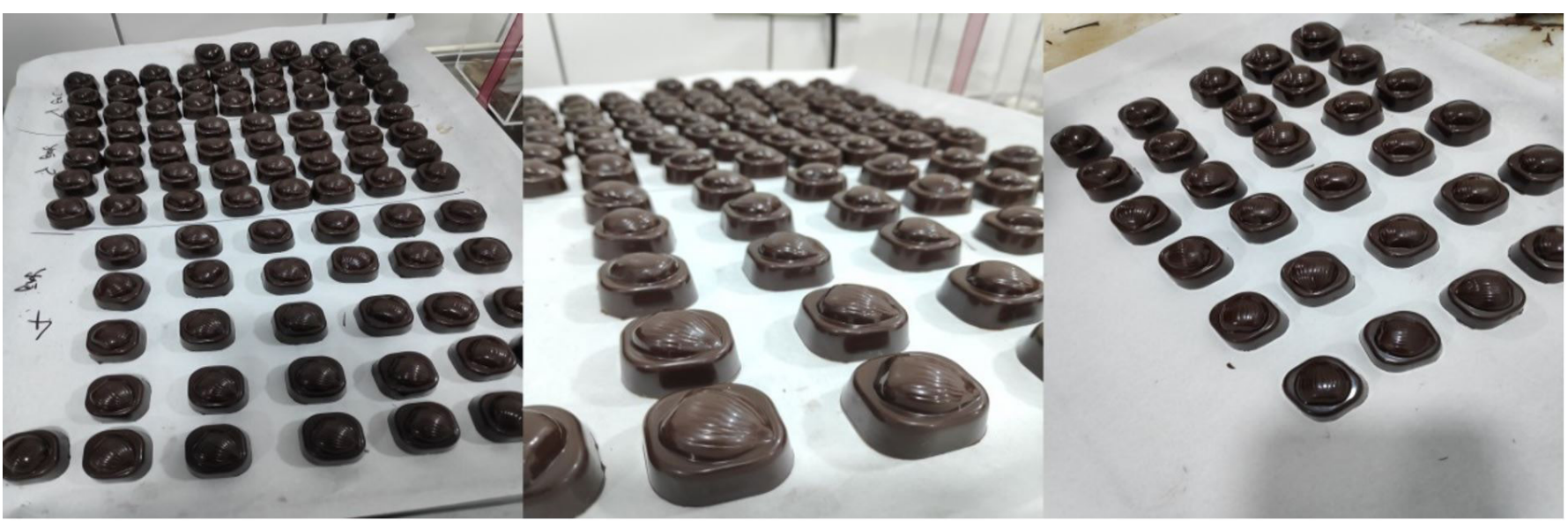

Figure 2. Removing the produced chocolate from the mold, grouping, and starting the storage process.

statistical package software. In determining which groups there is a difference, levels of difference were revealed by using the Chi-Square and Wilcoxon Signed Ranks test $(\mathrm{p}<0.05)$.

\section{Results and discussion}

\subsection{Findings regarding of sensory characteristics}

The sensory analysis of CG, PCP and CPS ganache filled chocolates, which were produced during the research, was performed on days 0,15 and 30 , and the sensory analysis results obtained correspondingly to the scores given by the panelists are shown in Table 3. Aguilar-Villa et al. (2020) stated that it is always necessary to make sensory evaluations of sugar-free chocolate samples. In addition, in the production of filled chocolate, it will be also very significant to evaluate the filled chocolate samples in a sensory sense, as the filling material affects the taste and texture of the final product.

Respectively to the scoring made on the chocolate samples, color values were determined to be between $3.0-4.7$ over 5 points. It has been determined that there was no significant difference between the values for 15 days (Table $3, p>0.05$ ). When the data of the chocolate produced with PCP ganache were examined, it has been seen that the color value started to decrease on day 30. It has been observed in the CPS ganache filled chocolate sample that day 0 and 15 values were the same, however it decreased on day 30. In the samples, the minimum value of 3.0 was determined on day 30 of CPS ganache filled chocolate, while the maximum value of 4.7 was determined on day 0 and 15 of the same chocolate. While there was no statistically significant difference in chocolates filled with CG, PCP and CPS ganache on days 0 and 15 during storage, a statistically significant difference was determined by day 30 . When the chocolates were compared within themselves, it has been observed that there was a significant difference only on day 15 , and it has been found that the chocolate having higher scores in terms of color characteristics with an average of 4.7 points was found to be CPS ganache filled chocolate (Table $3, \mathrm{p}<0.05$ ).
The sensory analysis of the chocolate samples proved that brightness values were determined to be between 2.6-4.7. No significant difference was observed between the values during the first 15 days (Table $3, \mathrm{p}>0.05$ ). When the chocolate samples produced with CG PCP and CPS ganache were examined, it has been observed that its value decreased between days 15 and 30 . While the minimum brightness value of 2.6 in the samples was determined on day 30 of PCP ganache filled chocolate, the maximum value of 4.7 was determined on day 15 of the chili pepper ganache filled chocolate. There was no statistically significant difference in the values of day 0 and 15 in all type ganache filled chocolates, which were examined in terms of brightness value during storage, however a statistically valuable difference was observed on day 30 . When the chocolates were compared within themselves, it has been found that there was a statistically significant difference only on day 15 , and it has been observed that the CPS ganache filled chocolate had a higher value in terms of brightness with an average score of 4.7 (Table 3, p $<0.05$ ).

Çağındı (2009) produced milk, bitter and white chocolates enriched with sunflower, linseed, oats and dried plums. Bitter chocolate samples among these had an average of 5 points in terms of appearance on day 0 , and an average of 5 points in the second measurement on day 30 , and assessed as very good by the participants. In their study, Rodríguez-Rodríguez \& AlbarránRodríguez (2019) developed two different bitter bonbon chocolates filled with almonds, and by means of sensory analysis, these chocolate samples received an average of 4.43 points in terms of color characteristics. Üzümcü (2017) developed chocolate samples with oats and blueberry additives in different ratios, and due to the sensory analysis of the samples, the average color characteristics of chocolates were scored with 4.4 and 4.15 in terms of general appearance. When the color and brightness characteristics of PCP ganache were examined, it has been found that they were similar to the findings in the studies of Üzümcü (2017) and Rodríguez-Rodríguez \& Albarrán-Rodríguez (2019). When the similarities are evaluated, it is thought that the similarities between the studies have been achieved by the fact that the products presented to the participants participating in the analysis are correctly tempered, they are not scratched 
Table 3. Sensory analysis values of CG, PCP and CPS ganache filled chocolates.

\begin{tabular}{|c|c|c|c|c|c|}
\hline \multirow[b]{2}{*}{ Sensory characteristics } & \multirow[b]{2}{*}{ Days } & \multicolumn{3}{|c|}{ Types of chocolate } & \multirow[b]{2}{*}{$\mathrm{p}$} \\
\hline & & Control group ganache & $\begin{array}{l}\text { Powdered chili pepper } \\
\text { ganache }\end{array}$ & $\begin{array}{l}\text { Chili pepper seed oil } \\
\text { ganache }\end{array}$ & \\
\hline \multirow{3}{*}{ Color (Appearance) } & Day 0 & $4.6 \pm 0.52^{x}$ & $4.4 \pm 0.84^{x}$ & $4.7 \pm 0.48^{x}$ & 0.414 \\
\hline & Day 15 & $4.3 \pm 0.68^{\mathrm{xb}}$ & $4.2 \pm 0.78^{\mathrm{xb}}$ & $4.7 \pm 0.48^{\mathrm{xa}}$ & $0.025^{\star}$ \\
\hline & Day 30 & $3.2 \pm 0.81^{y}$ & $3.0 \pm 0.94^{y}$ & $3.1 \pm 0.87^{y}$ & 0.655 \\
\hline $\mathrm{p}$ & & $0.001^{*}$ & $0.001^{*}$ & $0.000^{*}$ & \\
\hline \multirow{3}{*}{$\begin{array}{l}\text { Brightness } \\
\text { (Appearance) }\end{array}$} & Day 0 & $4.4 \pm 0.41^{\mathrm{x}}$ & $4.0 \pm 0.81^{\mathrm{x}}$ & $4.6 \pm 0.51^{\mathrm{x}}$ & 0.157 \\
\hline & Day 15 & $4.2 \pm 0.53^{\mathrm{xb}}$ & $4.1 \pm 0.73^{\mathrm{xb}}$ & $4.7 \pm 0.48^{\text {xa }}$ & $0.014^{*}$ \\
\hline & Day 30 & $2.9 \pm 0.94^{y}$ & $2.6 \pm 0.84^{y}$ & $3.0 \pm 0.81^{y}$ & 0.102 \\
\hline \multirow[t]{2}{*}{$\mathrm{p}$} & & $0.000^{*}$ & $0.000^{*}$ & $0.000^{*}$ & \\
\hline & Day 0 & $4.6 \pm 0.82^{\mathrm{x}}$ & $4.1 \pm 0.56^{\mathrm{x}}$ & $4.3 \pm 0.67^{\mathrm{x}}$ & 0.217 \\
\hline \multirow[t]{2}{*}{ Smell } & Day 15 & $4.4 \pm 0.75^{\mathrm{x}}$ & $4.3 \pm 0.67^{x}$ & $4.1 \pm 0.31^{\mathrm{x}}$ & 0.414 \\
\hline & Day 30 & $3.6 \pm 0.43^{y}$ & $3.1 \pm 0.73^{y}$ & $3.3 \pm 0.48^{y}$ & 0.217 \\
\hline \multirow[t]{2}{*}{$\mathrm{p}$} & & $0.002^{*}$ & $0.002^{*}$ & $0.003^{*}$ & \\
\hline & Day 0 & N/A & $3.7 \pm 1.05$ & $4.0 \pm 1.05^{\mathrm{x}}$ & 0.414 \\
\hline \multirow[t]{2}{*}{ Chili Taste } & Day 15 & $\mathrm{~N} / \mathrm{A}$ & $3.7 \pm 0.82$ & $3.7 \pm 0.67^{x y}$ & 1.000 \\
\hline & Day 30 & N/A & $3.1 \pm 0.87$ & $3.2 \pm 0.63^{y}$ & 1.000 \\
\hline \multirow[t]{2}{*}{$\mathrm{p}$} & & N/A & 0.086 & $0.023^{*}$ & \\
\hline & Day 0 & $4.2 \pm 0.44^{\mathrm{x}}$ & $4.3 \pm 0.82^{\mathrm{x}}$ & $4.1 \pm 0.56^{x}$ & 0.317 \\
\hline \multirow[t]{2}{*}{ Hardness } & Day 15 & $4.3 \pm 0.59^{x}$ & $4.1 \pm 0.73^{x}$ & $4.1 \pm 0.56^{\mathrm{x}}$ & 1.000 \\
\hline & Day 30 & $3.2 \pm 0.68^{y}$ & $2.7 \pm 0.94^{y}$ & $3.1 \pm 0.31^{y}$ & 0.157 \\
\hline $\mathrm{p}$ & & $0.001^{*}$ & $0.001^{*}$ & $0.001^{*}$ & \\
\hline
\end{tabular}

$\mathrm{x}, \mathrm{y}, \mathrm{z}$ shows the differences in the same column while $\mathrm{a}, \mathrm{b}, \mathrm{c}$ shows the differences in the same row. $\mathrm{p}<0.05^{\star}$. Scale 1: very bad, 2: bad, 3: acceptable, 4: good, 5: quite goodw.

during storage and presentation, and are moved without damage. After the follow-up of these standards, it has been concluded that the degree of similarity of the studies increased. It is thought that the differences between the studies may be due to differences of opinion among the participants or different ingredients added to the samples produced.

Upon the sensory analysis of the chocolate samples, the smell values were determined between 3.1 and 4.6 over 5 points. It has been determined that there was no significant difference between the values during the first 15 days of storage (Table 3, $\mathrm{p}>0.05)$. When the data of the chocolate produced with PCP ganache were examined, it has been seen that the odor value decreased on day 30 . This was also observed in the CPS ganache and CG ganache filled chocolate sample. In the samples, the minimum value of 3.1 was determined on day 30 of the chili pepper ganache filled chocolate, while the maximum value of 4.6 was determined on day 0 of the CG ganache filled chocolate. While the smell characteristics of chocolates filled with all type of samples were not considered statistically significant on days 0 and 15 during storage, a statistically significant difference was determined on day 30 . When the chocolates were compared within themselves, no difference was found between days 0 , 15 and 30 throughout the sensory analysis (Table 3, p>0.05).

Yildirim et al. (2016) found that the pomegranate chocolate samples received an average of 3.7 points. Üzümcü (2017) stated that as a deduction of sensory analysis, chocolate samples received an average score of 3.0 in terms of smell characteristics. Özat (2018) concluded that the average smell value of the $\beta$-glucan samples added to bitter chocolate at different proportions was 3.78. When the findings are examined, it is seen that the closest result to the study findings is in Atasoy's (2010) study. It has been seen that the values in the studies of Yildirim et al. (2016), Üzümcü (2017) and Özat (2018) were lower than the average values. The main reason for this difference is thought to be due to the components used in the studies having a strong aroma.

Based on the sensory analysis of the chocolate samples, it has been determined that the values examined in terms of chili taste values were between 3.1 and 4.0. It has been observed that there was no significant difference between the values during the first 15 days (Table 3, p>0.05). However, the CG ganache without chili products was not included in the sensory analysis at this stage. When the chocolate samples produced with PCP ganache were examined, it has been observed that values of days 0,15 and 30 were close to each other. It has been determined that between day 0-15 as well as day 15-30 showed difference in terms of chili taste properties in CPS ganache filled chocolate, however the difference has increased between day 0 and day 30 . While the minimum chili taste value of 3.1 was determined in the samples on day 30 of the PCP ganache filled chocolate, the maximum value of 4.0 was determined on day 0 of CPS ganache filled chocolate. In terms of chili taste values during storage, no significant difference was found between the analysis results of PCP ganache on days 0,15 and 30 . No statistically significant difference was found between days 0-15 and 15-30 for CPS ganache filled chocolate, however a statistically significant difference was observed between the values of day 0 and 30 . When the chocolates were compared within themselves, no significant difference was found between the days analyzed (Table 3, p>0.05). 
As per scoring made on the chocolate samples, the hardness values were determined to be between $2.7-4.3$ over 5 points. It has been determined that there was no significant difference between the values throughout 15 days (Table 3, $p>0.05$ ). When the data of the chocolate produced with PCP ganache and CG ganache were examined, it has been seen that the hardness value decreased on day 30. In CPS ganache filled chocolate, values of days 0 and 15 were the same, however it decreased on day 30 again. While the minimum value of the samples of 2.7 was determined on day 30 of PCP ganache filled chocolate, maximum value of 4.3 was observed on day 0 of the same sample and on day 15 of the CG ganache. While there was no statistically significant difference in all type ganache filled chocolates on days 0 and 15 during storage, a statistically significant difference was found by day 30 . When the chocolates were compared within themselves, no statistically significant difference was observed on any day (Table 3, p >0.05).

Atasoy (2010) determined the average hardness value of samples as $7.9(/ 2=3.95)$ at the end of the sensory analysis. Farinazzi-Machado et al. (2018) developed milk and bitter chocolate bonbons by filling ganaches containing mylose and glucomalt which are starch hydrolysates. As a result of sensory analysis, Farinazzi-Machado et al. (2018) found for bitter bonbons had texture properties of $6.43(/ 2=3.21)$ and $6,58(/ 2=3.29)$ on day 0 analysis, and 7,02 $(/ 2=3.51)$ and 7,38 $(/ 2=3.69)$ on day 30 analysis. When the study findings were examined, it has been observed that they are higher on first day tests compared to findings of Atasoy (2010) and Farinazzi-Machado et al. (2018), however, higher scores were found in the study by FarinazziMachado et al. (2018) on day 30. The reason for this difference is thought to be due to the use of whey protein concentrate and milk powder in Atasoy's study, and the use starch hydrolysates by Farinazzi-Machado et al. (2018).

\subsection{Findings regarding of physicochemical measurements}

Texture perception is a dynamic oral process before and during chewing. The texture and appearance of chocolate are key characteristics in consumer selection and acceptability (Afoakwa, 2010: 103). Therefore, it is necessary to evaluate the physicochemical properties of these chocolates for the condition and quality of each final product (Melo et al., 2020: 326). Throughout the study, physicochemical analysis of the CP, PCP and CPS ganache filled chocolate produced in three repetitions was carried out on days 0,15 and 30 by taking three measurements. In this context, analyzes were carried out on the texture (penetration), color properties of chocolates and viscosity values of ganaches, and the results are presented in Table 4 and Table 5.

Physicochemical analysis performed on chocolate samples shows that the texture (penetration) values were determined to be between $n=27.68-30.20$. Throughout 15 days, no significant changes were observed in the values of CG ganache and PCP ganache filled chocolate, however, a statistically significant difference was found on day 30 compared to the other days (Table 4, $\mathrm{p}<0.05$ ). When the data of chocolate produced with CPS ganache were analyzed, significant differences were observed in the texture value on days 0,15 and 30 . The minimum value in the samples was determined as $n=27.68$ on day of 15 CPS ganache filled chocolate, while the maximum value was determined with $\mathrm{n}=30.20$ on day 30 of the PCP ganache filled chocolate. When all type samples were compared within themselves, no significant difference was found on day 0 , however, a significant difference was determined on days 15 and 30 (Table 4, p<0.05).

In this study, Koca (2011) subjected the chocolate samples produced with different conching conditions to texture analysis and stated that the values she obtained were minimum $n=35.5$ and maximum $n=43.2$. Özhan (2012), on the other hand, measured the penetration values with a different method in texture analysis, and obtained penetration values of minimum $n=9.6$ and maximum $n=13.9$ on samples with chocolate containing different levels of prebiotic components in the measurements conducted at a temperature of $25^{\circ} \mathrm{C}$. Toliba (2018) subjected the chocolate samples prepared with dried Indian cherry additives to the texture analysis, and obtained following penetration values: $\mathrm{n}=7.88$ for $20 \%$ additives, $\mathrm{n}=15.99$ for $30 \%$ additives and $\mathrm{n}=55.18$ for $50 \%$ additives on chocolates with different contents of dried Indian cherry additives. This value was found to be $n=63.47$ in the sample where they added the dried Indian cherries into the chocolate as a whole. Özat (2018) determined the average penetration value in the samples developed with bitter chocolate as $n=87.46$. No similarity was found between the findings and these studies. The reason for this is thought to be due to the measurements being made at different temperatures, operation of the measuring devices under different conditions, thickness differences that may occur in the molding of the samples, or other functional nutrient additives during chocolate production.

Thanks to the physicochemical analyses conducted on the chocolate samples, color $L^{*}$ values were determined to be between 57.40-66.56. No significant changes were observed in $L^{*}$ value of CG ganache and PCP ganache filled chocolate on days 0 and 15, however, it has been found that the value decreased on day 30 . When the data of CPS ganache filled chocolate was analyzed, a significant difference was observed in $\mathrm{L}^{\star}$ value between days 0 , 15 and 30 (Table 4, p<0.05). The minimum value of 57.40 in the samples was determined on day of PCP filled chocolate, while the maximum value of 66.56 was determined on day 0 of the CG ganache filled chocolate. When the color $\mathrm{L}^{*}$ value of CPS ganache filled chocolate was examined on all days of measurement during storage, a statistically significant difference was observed. While there was no statistically significant difference in CG ganache and PCP ganache filled chocolate on days 0 and 15, a statistically significant difference has been determined by day 30 . When the chocolates were compared within themselves, it has been found that there was a significant difference on all days of measurement. CG ganache filled chocolate sample was observed to have a higher value on all days compared to PCP ganache filled chocolate and CPS ganache filled chocolate. Corresponding values of CG ganache filled chocolate were determined as 66.56 on day $0,66.23$ on day 15 and 64.59 on day 30 (Table 4, p<0.05).

Çağındı (2009) stated that the $\mathrm{L}^{*}$ value in bitter chocolate samples was at least 27.72 and maximum 29.74 on day 0 as a consequence of the color analysis of the chocolate samples they developed with flaxseed, sunflower seeds, oats/rice cakes and damson plum. During the tests performed on day 30, these 
Table 4. Physicochemical analysis values of CG, PCP and CPS ganache filled chocolate.

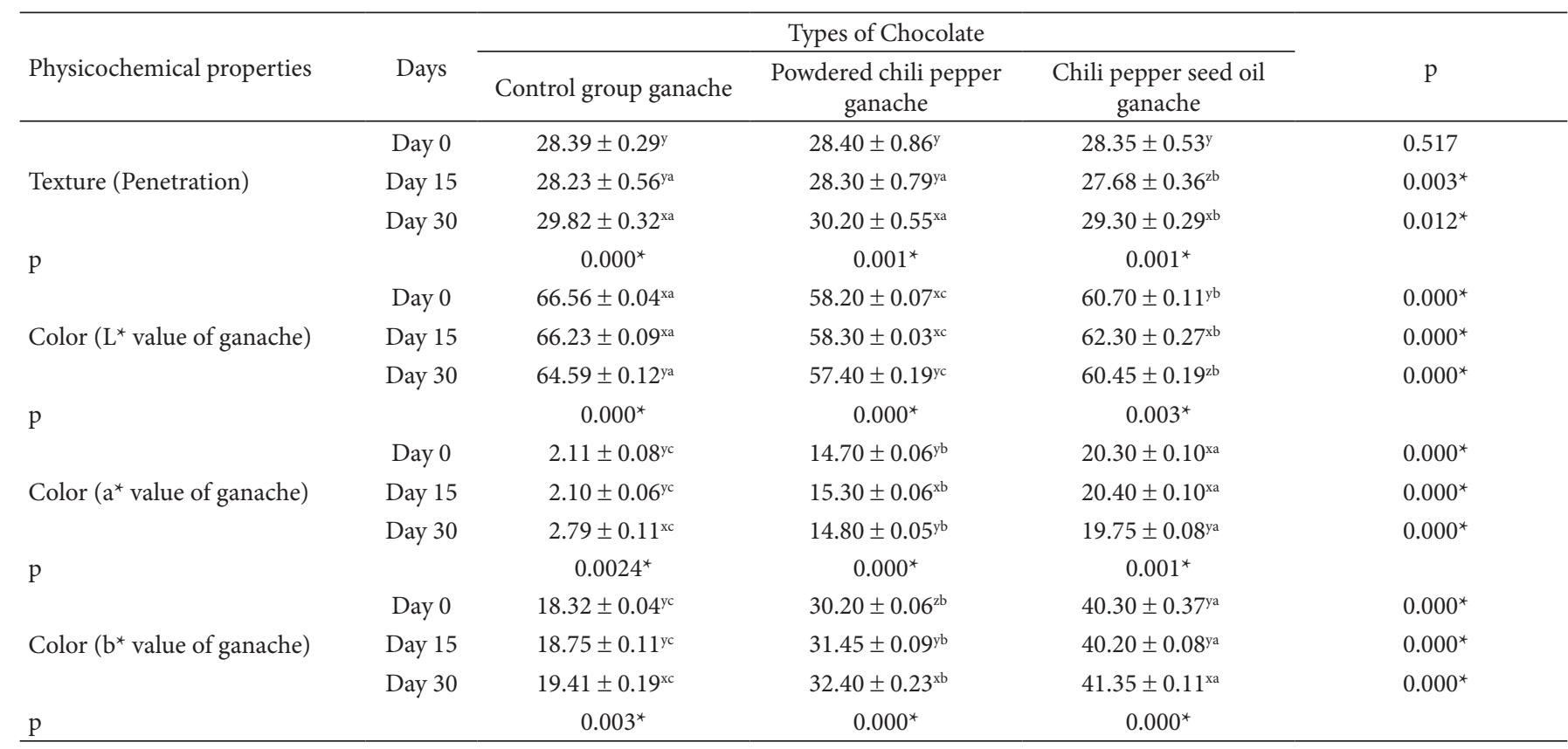

$\mathrm{x}, \mathrm{y}, \mathrm{z}$ shows the differences in the same column while $\mathrm{a}, \mathrm{b}, \mathrm{c}$ shows the differences in the same row. $\mathrm{p}<0.05^{\star}$.

values changed to be minimum 27.70 and maximum 30.00 . Özhan (2012), stated that the $L^{*}$ value of the samples was minimum 34.94 and maximum 38.88 as a result of the findings that they developed chocolates containing different levels of prebiotic ingredients. Kang et al. (2014) developed different amounts of sweetener and coffee-added ganaches in their study and determined the $\mathrm{L}^{*}$ value of these ganaches as 8.9 and 14.7. Yücekutlu (2015) produced chocolate samples by using different sweeteners, and by the end of color analysis they made on bitter chocolate samples and found the $\mathrm{L}^{\star}$ value as minimum 24.27 and maximum 24.87. Üzümcü (2017) stated that the $L^{*}$ value of the samples they produced by adding oatmeal and blueberries was minimum 34.77 and maximum 37.67 . When compared with the findings obtained in our study, no similarity was found with these studies. The reasons of this condition are thought to be production of samples with different levels of raw material contents, different ganache types, contamination and moisture that may occur during molding.

It is proven that the physicochemical analysis conducted on the chocolate samples, color $\mathrm{a}^{*}$ values were determined to be between 2.10-20.40. Throughout 15 days, no significant changes were observed in the values of both all type ganache filled chocolates, however, it has been determined that the values decreased on day 30 . While the minimum value of 2.10 in the samples was determined on day 15 of CG ganache filled chocolate, the maximum value of 20.40 was observed on day 15 of CPS ganache filled chocolate. When the chocolates were compared within themselves, it has been found that there was a significant difference on all days of measurement. It has been observed that the CPS ganache filled chocolate sample had a higher value on all days compared to PCP ganache filled chocolate, and these values were 20.30 on day $0,20.40$ on day 15 , and 19.75 on day 30 (Table 4, $\mathrm{p}<0.05$ ).
Çağındı (2009) stated that a ${ }^{\star}$ values in bitter chocolate samples were minimum 2.73 , maximum 4.94 on day 0 , and minimum 2.82 and maximum 5.67 on day 30 . In the study conducted by Kang et al. (2014), these values were observed between -3.57 and 1.16. In the study conducted by Yücekutlu (2015), it has been observed that the $\mathrm{a}^{*}$ value of bitter chocolate samples was minimum 3.23 and maximum 5.20. Üzümcü (2017) determined the $\mathrm{a}^{\star}$ value of the samples in consequences of color analysis as minimum 10.82 and maximum 13.02. When the findings were compared with these studies, similar results were obtained in the studies of Çağındı (2009) and Yücekutlu (2015) in terms of $\mathrm{a}^{*}$ value. It has been observed that the highest $\mathrm{a}^{*}$ value obtained in the study conducted by Üzümcü (2017) was similar to the $\mathrm{a}^{*}$ values determined for PCP ganache filled chocolate on days 0 and. The difference between the studies in terms of $a^{*}$ value is thought to be caused by the same reasons as in the $\mathrm{L}^{*}$ value. It is thought that the similarity created by the study of Üzümcü (2017) is not due to the chocolate raw material used. The reason for this is that Üzümcü (2017) used milk chocolate. However, Üzümcü (2017) added red and purple dried blueberries to milk chocolate. The main source of similarity is thought to be the darkening of color caused by this addition.

At the end of physicochemical analysis performed on chocolate samples shows that color $b^{*}$ values were determined to be between 18.32-41.35. No significant difference was observed in the values of CG ganache and CPS ganache filled chocolate for 15 days, however, it has been found that the value increased on day 30 . When the data of PCP ganache filled chocolate was analyzed, a significant difference was found between the values on days 0,15 and 30 (Table $4, p<0.05$ ). The minimum value of 18.32 was determined on day 0 of powdered CG ganache filled chocolate, while the maximum value of 41.35 was determined on day 30 of the CPS ganache filled chocolate. When the chocolates were compared within themselves, it has been found 
that there was a significant difference on all days of measurement. CPS ganache filled chocolate sample was observed to have higher a $^{*}$ value as well as $b^{\star}$ value compared to PCP ganache filled chocolate on all days. Corresponding values of CPS ganache filled chocolate were determined as 40.30 on day $0,40.20$ on day 15 and 41.35 on day 30 (Table 4 , p $<0.05$ ).

Çağınd ${ }_{1}$ (2009) determined the $b^{*}$ values of the samples prepared with bitter chocolate to be minimum 3.98 and maximum 5.33 on day 0 , and stated that the values increased with a minimum of 3.94 and a maximum of 5.93 in the tests performed on day 30. Kang et al. (2014) determined in their study that the $b^{*}$ value of their samples was between 1.61 and 4.99. In Üzümcü's (2017) study, these values were determined as minimum 10.50 and maximum 12.07 . When compared with the findings, it has been observed that the samples found in the studies were not similar in terms of $b^{*}$ value. The difference between the values is thought to be due to the value differences that may occur in terms of measurement conditions and the measurement devices used.

During the production of chocolate samples, viscosity analyzes were performed on day 0 with the samples taken from the ganache, and the viscosity values were determined to be between 120.02-150.05 including the CG ganache by means of these analyzes. The ganaches were not stored separately for viscosity measurement, the analyzes were conducted in three repetitions on day 0 , the day of production. When ganaches were examined within themselves, significant differences were observed in terms of viscosity values (Table $5, \mathrm{p}<0.05$ ). Among the ganache samples, the minimum value belongs to CPS ganache with 120.02 , while the maximum value belongs to the PCP ganache with 150.05 . The tests performed on day 0 have showed that a statistically significant difference has been found between the ganaches. (Table 5, $\mathrm{p}<0.05$ ).

Atasoy (2010) measured the viscosity values of the chocolate samples produced as minimum $\mathrm{cP}=123.00$ and maximum $\mathrm{cP}=162.00$. On the other hand, Gülfidan (2016) determined the minimum viscosity value as minimum $\mathrm{cP}=31.20$ maximum $\mathrm{cP}=115.00$ in samples developed with different ratios to produce different tooth-friendly chocolates. When the findings are examined, it is seen that although there are similarities between values, there are more differences. The reason for this is thought to be mainly due to the differences in the solid matter ratio of the sample used in viscosity analysis and the temperature of the sample during analysis.

\section{Conclusion}

The aim of this study was to develop standard recipes of chili ganache filled chocolate samples for chocolate production centers of artisan chocolate enterprises, patisseries, hotel businesses and to investigate different properties. In the conclusion of the production and sensory analysis carried out in this context, when the ganache and the final product chocolate samples were examined, it was determined that the CPS ganache filled chocolate was more liked and consumable by the panelists. In terms of physicochemical properties, it has been seen that the CPS ganache filled chocolate samples had lower penetration and higher brightness values compared to the PCP ganache filled chocolate. As ganache, it is thought that the CPS ganache
Table 5. Physicochemical analysis and viscosity values of CG, PCP and CPS ganache.

\begin{tabular}{lc}
\hline Ganache types & Viscosity values of ganaches $(\mathrm{cP})$ \\
\hline Control group ganache & $142.01 \pm 0.33^{\mathrm{y}}$ \\
Powdered chili pepper ganache & $150.05 \pm 0.16^{\mathrm{x}}$ \\
Chili pepper seed oil ganache & $120.02 \pm 0.16^{\mathrm{z}}$ \\
$\mathrm{p}$ & $0.000^{\star}$ \\
\hline $\mathrm{x}, \mathrm{y}, \mathrm{z}$ shows the differences in the same column. $\mathrm{p}<0.05^{*}$.
\end{tabular}

having a creamier structure than CG ganache and PCP ganache. Therefore, CPS ganache filled chocolate will provide a better experience for consumers.

Keeping the quality standards of chili ganache filled chocolate samples at the highest level is especially effective under storage conditions. Throughout the study, the samples were constantly stored at $16-18^{\circ} \mathrm{C}$, away from sunlight, with low humidity, and it has been observed that deterioration and blooming occurred from day 15 of this storage period. For this reason, it is recommended that the ganache filled chocolates containing dairy products should be stored and consumed within 15 days.

When the samples produced in the study were evaluated, powdered chili pepper and chili pepper seed oil were used as chili sources. Different applications can be realized with chili pepper ganaches to be obtained from different sources in future products and scientific studies. Considering the health benefits of both bitter chocolate (Steinberg et al., 2003: 218; Buijsse et al., 2010: 1622; Milagres et al. 2020: 310) and chili pepper (Hala, 2011: 1121; Guzmán \& Bosland, 2017: 186; Chopan \& Littenberg, 2017:8), it becomes important to consume study samples and products with similar content.

Standardization of production has an important value in the process of new product development and in food enterprises. Therefore, it is thought that different enterprises working on chocolate can improve their standard recipe ranges. In addition, it is anticipated that it will contribute to businesses in terms of selling chili pepper ganache chocolate in the market, offering different flavors to guests, and expanding the market region. The sensory analysis results obtained proved that the samples are consumable. This result will provide good support for the launch of a new product in the market.

\section{Acknowledgements}

This manuscript was supported by the project number 191322003 by The Coordinator of Scientific Research Projects of Necmettin Erbakan University. It was summarized from Berkay SEÇUK's master thesis.

\section{References}

Afoakwa, E. O. (2010). Chocolate science and technology (1st ed.). Oxford: Wiley-Blackwell.

Afoakwa, E. O., Paterson, A., \& Fowler, M. (2007). Factors influencing rheological and textural qualities in chocolate-a review. Trends in Food Science \& Technology, 18(6), 290-298. http://dx.doi.org/10.1016/j. tifs.2007.02.002. 
Aguilar-Villa, C., Acosta-Otálvaro, E. V., Rodríguez-Sandoval, E., \& MazoRivas, J. C. (2020). Sucrose-free milk chocolate manufacture using bulking agents and non-caloric sweetener. Food Science and Technology (Campinas), 40(1), 62-67. http://dx.doi.org/10.1590/fst.32418.

Atasoy, G. (2010). Farklı oranlarda peynir altı suyu protein konsantratı ilavesiyle üretilen çikolataların kalite karakteristiklerinin belirlenmesi üzerine bir araştırma (Master's thesis). Institute of Sciences, Namık Kemal University, Tekirdağ.

Beckett, S. T. (2008). The science of chocolate (2nd ed.). Cambridge: Royal Society of Chemistry.

Buijsse, B., Weikert, C., Drogan, D., Bergmann, M., \& Boeing, H. (2010). Chocolate consumption in relation to blood pressure and risk of cardiovascular disease in German adults. European Heart Journal, 31(13), 1616-1623. http://dx.doi.org/10.1093/eurheartj/ ehq068. PMid:20354055.

Çağındı, Ö. (2009). Ayçiçeği, keten tohumu, yulafve mürdüm eriği kurusu ile zenginleştirilmiş sütlü, acı (bitter) ve beyaz çikolataların rafömrü boyunca bazı fiziksel, kimyasal ve duyusal özelliklerinin araştırılması (Master's thesis). Institute of Sciences, Ege University, İzmir.

Chopan, M., \& Littenberg, B. (2017). The association of hot red chili pepper consumption and mortality: a large population-based cohort study. PLoS One, 12(1), 1-10. http://dx.doi.org/10.1371/journal. pone.0169876. PMid:28068423.

Farinazzi-Machado, F. M. V., Giannoni, J. A., Marinelli, P. S., Jesus, J. R., Santos, N. C., \& Cabral, T. M. (2018). Effects of starch hydrolysates on the physical, chemical and sensory characteristics of filled bonbons. International Journal of Modern Agriculture, 7(1), 1-8. http://dx.doi. org/10.17762/ijma.v7i1.72.

Gülfidan, O. G. (2016). Diş dostu çikolata üretimi (Master's thesis). Institute of Sciences, Süleyman Demirel University, Isparta.

Günel, M. (2018). Dünya yepyeni bir çikolata türüyle tanışıyor: Karşınızda ruby çikolata. Retrieved from https://listelist.com/ruby-cikolata-nedir/

Guzmán, I., \& Bosland, P. W. (2017). Sensory properties of chile pepper heat-and its importance to food quality and cultural preference. Appetite, 117, 186-190. http://dx.doi.org/10.1016/j.appet.2017.06.026. PMid:28662907.

Hala, M. A. (2011). Comparative antioxidant activity study of some edible plants used spices in Egypt. The Journal of American Science, 7(1), 1118-1122.

Kang, S., Lee, J. S., Jeong, A., Kim, E., \& Park, S. (2014). The effects of using artificial sweeteners and coffee grounds in chocolate filling on quality characteristics and glycemic index. Journal of Applied Biological Chemistry, 57(4), 307-312. http://dx.doi.org/10.3839/ jabc.2014.048.

Kaya, A., \& Şekeroğlu, G. (2012). Çikolata. TSE Standart Ekonomik ve Teknik Dergi, 51(604), 21-25.

Koca, S. (2011). Bitter çikolatanın fizikokimyasal özellikleri üzerine konçlama şartlarının etkisi (Master's thesis). Institute of Sciences, İstanbul Teknik University, İstanbul.

Lawless, H. T., \& Heymann, H. (1998). Sensory evaluation of food: principles and practices (1st ed.). USA: Chapman \& Hall.
Melo, C. W. B., Bandeira, M. J., Maciel, L. F., Bispo, E. S., Souza, C. O., \& Soares, S. E. (2020). Chemical composition and fatty acids profile of chocolates produced with different cocoa (Theobroma cacao L.) cultivars. Food Science and Technology, 40(2), 326-333. http://dx.doi.org/10.1590/fst.43018.

Milagres, M. P., Silva, D. M., Pereira, I. O., Senhorinho, L. M., Goulart Sant'Ana, A. E., \& Matos, T. B. (2020). Health benefits of chocolate consumption with high concentration of cocoa incorporated from triterpenic acids, isolated from Mansoa hirsuta DC. Food Science and Technology, 40(Suppl. 1), 305-311. http://dx.doi.org/10.1590/ fst.10519.

Özat, T. E. (2018). B-Glukan ilavesi ile fonksiyonel çikolata çeşitlerinin (sütlü, bitter, beyaz ve sürülebilir kakaolu findık kreması) geliștirilmesi (Master's thesis). Institute of Sciences, Ankara University, Ankara.

Özhan, B. (2012). Farklı düzeylerde prebiyotik bileșen içeren çikolataların bazı yapısal özelliklerinin belirlenmesi (Master's thesis). Institute of Sciences, Ankara University, Ankara.

Palacıoğlu, S. (2003). Çikolata sektör profili. İstanbul: Istanbul Chamber of Commerce.

Rodríguez-Rodríguez, J., \& Albarrán-Rodríguez, E. (2019). Development of bitter chocolate bonbon stuffed with almond (Prunus Amygdalus Var. Dulcis) and its physicochemical evaluation and sensory acceptance. Journal of Food Science and Engineering, 9, 217-224. http://dx.doi. org/10.17265/2159-5828/2019.06.004.

Silva, H. L. A., Balthazar, C. F., Silva, R., Vieira, A. H., Costa, R. G. B., Esmerino, E. A., Freitas, M. Q., \& Cruz, A. G. (2018). Sodium reduction and flavor enhancer addition in probiotic prato cheese: contributions of quantitative descriptive analysis and temporal dominance of sensations for sensory profiling. Journal of Dairy Science, 101(10), 8837-8846. http://dx.doi.org/10.3168/jds.201814819. PMid:30077456.

Steinberg, F. M., Bearden, M. M., \& Keen, C. L. (2003). Cocoa and chocolate flavonoids: implications for cardiovascular health. Journal of the American Dietetic Association, 103(2), 215-223. http://dx.doi. org/10.1053/jada.2003.50028. PMid:12589329.

Toliba, A. O. (2018). Quality characteristics of compound chocolate enriched with dried Indian cherry fruit pulp. Suez Canal University Journal of Food Sciences, 5(1), 91-97. http://dx.doi.org/10.21608/ scuj.2018.59347.

Üzümcü, Z. (2017). Belirli oranlarda yulaf ezmesi ve yaban mersini ilavesi ile üretilen sütlü çikolatanın bazı özelliklerinin belirlenmesi (Master's thesis). Institute of Sciences, Kahramanmaraş Sütçü İmam University, Kahramanmaraş.

Yıldırım, A., Çetin, S., Öğretmen, H., Sari, P., \& Hayoğlu, İ. (2016). Narın çikolata üretiminde kullanımı. Harran Tarım ve Gıda Bilimleri Dergisi, 20(1), 12-19. http://dx.doi.org/10.29050/harranziraat.194283.

Yllmaz, S. D. (2018). Kültür ve popüler kültürde çikolatanın yeri ve öneminin kültür, tüketim, sağllk ve lezzet bağlamlarında incelenmesi: Gaziantep örneği (Master's thesis). Institute of Social Sciences, Gaziantep University, Gaziantep.

Yücekutlu, M. (2015). Effect of some intense sweeteners on rheological, textural and sensory properties of chocolate (Master's thesis). Middle East Technical University, Ankara. 